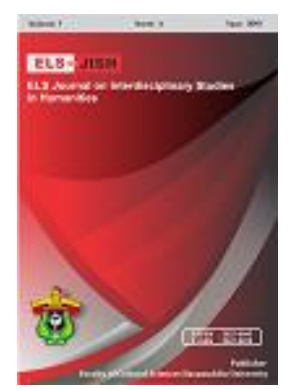

ELS-JISH

ELS Journal on Interdisciplinary Studies on Humanities

Volume 1 Issue 3, 2018

ISSN (print) : 2621-0843

ISSN (online) : 2621-0835

Homepage : http://journal.unhas.ac.id/index.php/jish

\title{
The Power of Woman in Weiner's Little Earthquakes
}

\author{
Andi Inayah Soraya ${ }^{1}$
}

inayah.soraya@yahoo.com

\begin{abstract}
This research aimed to explain the power of women as a good wife and mother to face many problems in their life. It applies psychological Maslow's theory, who proposes five steps of Hierarchy of Needs covering Psychological Needs, Safety Needs, Belongingness and Love Needs, Esteem Needs, and Self-Actualization. This research used descriptive qualitative method which used to analysis and explained how the psychological theory was applied in literary work focused on character analysis in this novel. The data in this research were taken from the dialogue and narration of the novel. The finding of analysis indicates that there are four mothers struggling to fulfill their needs in life. They are Becky, Kelly, Ayinde, and Lia. Based on the novel, those of characters have a lot of problems in their life. Not only problems, as human they also have kind of needs. To analyze their needs, the researcher connected with Hierarchy of needs by Maslow and found that they can fulfill all the steps start from Psychological, Safety, Belongingness, Esteem, and the high step is Self-Actualization. In spite of they need struggling which is not easy. But from their intention, support from each other called sisterhood, and love form people around them, they can solve their problem and fulfilled their needs.
\end{abstract}

Keywords: Jennifer Weiner, Abraham Maslow, Hierarchy of needs

How to cite: Soraya, A. I. (2018). The Power of Woman in Weiner's Little Earthquakes. ELS Journal on Interdisciplinary Studies in Humanities, 1 (3), 350-356.

\section{Introduction}

Little Earthquakes brings readers a tale of romance, friendship, forgiveness, and extreme sleep deprivation, as four very different women navigate. It showed the wonderful and perilous transitions as new motherhood. There are long processes for them in life, started from making relationship, marriage, to be the wife, pregnant, have baby, have conflict, and to be the best mother for their family.

The interesting word of the novel is "motherhood". It means that the subject is mothers. As character in the novel, mother surely have special characteristic which develop the story called characterization. Characterization is very important aspect because it is a literary device that is used step by step in literary works to highlight and explain the detail about a character in a story. It is relevant with Card (1988:54) states that "characterization is not a virtue but a technique".

This novel consists of four major characters. The first is Lia, who had to face the reality for the death of her son. She has recently lost a baby to SIDS is known as cot

\footnotetext{
${ }^{1}$ English Department, Faculty of Cultural Sciences, Hasanuddin University
} 
death or crib death, is the sudden unexplained death of a child less than one year of age. Another character is Becky, an overweight but thoroughly appealing chef at a chic bistro. She was married to an adoring doctor and living in a cozy row house but unfortunately she gets troubles with her parents in law. Next is Kelly, she is going to have everything perfect. Then her husband loses his job and her world is turned upside down as she goes back to work when her baby is twelve-weeks-old. She struggles with exhaustion while she tries to do it all. Although she needs help, she refuses to let her husband do anything and is furious when he doesn't. He finally leaves her. The last is Ayinde the gorgeous wife of an NBA superstar and also as a rich wife but in other hand her husband was affair with other women.

All of the characters have part of life which interesting to analyze. For example how they support each other, solve their problem, fulfill their needs, and survive to their life. To analyze the characters in this novel, the researcher used psychological aspect using Maslow's theory because it matched to achieve the purpose of this study.

Onah (2015) remarks that in 1943 that Brandeis University professor of psychology, Abraham Maslow as a renowned researcher in the study of human needs and motivation came up with his hierarchy of needs theory with a proposal that people are motivated by five levels of needs namely: (1) Physiological needs, (2) safety needs, (3) belonging needs, (4) esteem needs and (5) self-actualization needs.

Psychological criticism by applying psychological theory of Maslow that Human Basic Motivation refers to Hierarchy of Needs. It is a motivational theory in psychology comprising a five-tier model of human needs, often depicted as hierarchical levels within a pyramid. As Paris mentions (1996:3) "Psychoanalysis deals with human beings in conflict with themselves and each other, and literature portrays and is written and read by such people."

The hierarchy of needs five-stage model includes of the first is Biological and physiological needs for example air, food, drink, shelter, warmth, sex, sleep. Todaro and Smith (2009) refer to human basic needs of food, shelter, health and reproduction as life sustaining basic human needs.

Second is a Safety need - protection from elements, security, order, law, stability, freedom from fear. Santrock (2001) states that the emphasis that safety needs on an ensuring survival of people in such a situation as protection from war and crime. Indeed, chaotic situations, social disorders, social disturbance, social and physical dangers are characterized by a lot of uncertainties that threaten peaceful co-existence of people in various communities in the society.

The third is Love and belongingness needs - friendship, intimacy, trust, and acceptance, receiving and giving affection and love. Affiliating, being part of a group (family, friends, work). Forth is Esteem need - which Maslow classified into two categories: (i) esteem for oneself (dignity, achievement, mastery, independence) and (ii) the desire for reputation or respect from others (e.g., status, prestige). Maslow indicated that the need for respect or reputation is most important for children and adolescents and precedes real self-esteem or dignity. And the last is Self-actualization needs - realizing personal potential, self-fulfillment, seeking personal growth and peak experiences.

\section{Research Method}

\subsection{Type of Research}


This study uses descriptive qualitative design in describing how the characters are able to fulfill their needs in Jennifer Weiner's Little Earthquakes under Maslow's psychological approach Hierarchy of Needs.

\subsection{Source of Data}

The data used by the researcher in this research were taken from Jennifer Weiner novel The Little Earthquakes. The researcher uses the novel which was published 2011 a as the primary data and the secondary data were taken from various books, articles, journals and website on internet which relevant to this research.

\subsection{Method of Data Collection}

Data Collection in this research is divided into four steps. The first is close reading, the step to understand the data found in the novel and to determine the existence of the data throughout the novel Little Earthquakes. Second is brainstorming is the step to jot down all the data. Next is selecting is to mark the spreading data from brainstorming. The writer selects the conversation of major characters and minor characters in Little Earthquakes in terms of friendship, love, duty, and doomed.

\subsection{Method of Data Analysis}

Data Analysis Technique in this research is following some steps. The first step is classifying the data based on the information about main character needs that contained in the data. The second step is finding the answer of research problems by identifying the kinds of needs that showed by the main character in the movie and analyzing the influence of the main character desire in fulfilled his needs. The third was make conclusion for answering the research questions based on result of the research.

\section{Findings}

\subsection{Biological and Physiological Needs}

This needs directly related to survival, which we share with other animals. Included are the needs for food, water, elimination, and sleep. Lia, Becky, Kelly, and Ayinde are human whose need food and water. Lia was completed this need. Merely, she was traumatic with little earthquakes that take her baby, and it was influence to her appetite. For Becky, she doesn't have problem of this need. She also serves food and drink to many people, every day.

"It was three o'clock in the afternoon, and he little kitchen was already steamy and warm with the scent of braised pork shoulder in a cinnamon-spiked sauce, cilantro and garlic salsa, and roasting peppers, for the savory flan. Becky took a deep, happy breath and stretched her arms over her head". (LE, 2004:8).

It was I because Becky was the owner of restaurant and she laws the chef in there. Talk about Becky's Restaurant, there many people go there. Kelly is one of member of there. She like go Mas Restaurant to enjoy special food in there.

"I just love your restaurant. Chicken in mole sauce. It was delicious. (LE, 2004: 16).

From this quotation, we can see that Kelly can fulfill a food and drink needs. Similar with her friends, Ayinde doesn't have problem to this needs. She has luxury life, which no problems of food and drink. She can eat anything because her maid will serve her. As Winner said, "Ayinde nodded, thinking how stranger it was, because in her life, all by 
yourselves meant all by yourself except for the maid, the cook, and the driver". (LE, 2004:105).

\subsection{Safety Need}

The next level of the needs is safety. Unfortunately, little earthquakes makes Lia feel unsafe again.

"It had been this way since it happened. Nothing could make me feel safe. Not my husband,

San, holding me, not the sad-eyed, sweet-voiced therapist he'd found, the one who'd told me". (LE, 2004:4).

The only one who makes Lia feel safe when she get trauma from little earthquakes is her mother.

"You're my daughter," she continued, "and you'll always have a place here. (LE, 2004: 61).

Another character is Kelly. Actually Kelly is strong woman. She has brief characterization, which bring her in stability condition. Next is Ayinde, as popular basketball's wife, sometimes she feel not safety when she in public.

'Listen. My husband ...' her forehead furrowed. "Do you think there's a back door to the hospital or something like that? I don't want anyone to see me like this". (LE, 2004: 17).

But fortunately, her husband prepare bodyguard for Ayinde. The quotation reveal that all of characters can also gratify their second basic needs namely safety need.

\subsection{Belongingness and Love Needs}

Based on this novel, the researcher is strongly believed that this need can be fulfilled by all characters. Because the power of belongingness and love needs can they get from theirs. They have the power of friends or especially for them called motherhood.

Besides that, the figure of husband is very important to develop their love. Although some of their husbands especially Ayyinde and Kelly make her disappointed. For Lia, she has good husband that never left her until the bad condition. And in the end of story Lia back to her husband and make good relationship with her mother.

"I saw Sam and my mother, walking toward me from Walnut Street, arm in arm. Wonders never do cease, I thought, as I got to my feet. (LE, 2004: 412).

Becky was happy to find Andrew in her life. He loves her very much. It prove when Becky in being in labor.

"I'm feeling great," Becky said, leaning her head against his chest. "But I know it's still early.

"She squeezed his hand. "Stay with me okay?"

“I wouldn't leave for anything, "he said. (LE, 2004: 144).

Although Kelly was disappointed to her husband because he being unemployment when they will get baby. But she still gets affectionate from her husband, and her sister Mary, Terry and Dore. They help her when the first day, Kelly come back to her apartment after she being labor.

"Okay, "Kelly called, as she walked into her apartment with baby Oliver in her arms and her husband and her dog and her sisters in her wake. "Terry, there is lasagna in the freezer. Preheat the oven to 350 degrees and bake it for an hour. Mary, would you mind bringing my 
laptop into the bedroom? I want to send out an announcement...oh, Steve if you go to the My Documents folder on the desktop, can you please enter once wet diaper? (LE, 2004:161).

Belongingness and love needs also get from mother. It comes to Ayinde life. She has lovely mother who always give her affection.

"Hello, Mother."

"Hello my love. How are you doing?"

“Just fine,"Ayinde said as Julian blatte. (LE, 2004:131).

From those quotations, finally all character need of belongingness and love has been fully gratified, even though to achieve them pass so much struggle.

\subsection{Esteem need}

Lia as ex-artist, and her physical appearance is not good looking, so there is no people will care with her, when she comeback to Philadelphia. She does not get esteem from people around her. Fortunately, she meets Becky, Kelly, and Ayinde who understood her and give esteem.

Living with her mother-in law called Mimi, Becky doesn't get esteem from her. Mimi always have different point of view with Becky. In this case, Becky tries to be calm because she realize that Mimi is her husband's mother, and it means she must give esteem to her.

"Just talk to her," Andrew said. "She's lonely."

"She is crazy, Becky though. "Okay she said." Next time she calls. I'll talk to her." (LE, 2004:8).

Different with Becky, Kelly is work hard to get esteem from people around her. It is impact of her character as perfectionist woman. And for Ayinde, all people always talk about her family because her husband was public figure. So, for her get esteem from people around her is not special again. These above quotations evidently show that finally Lia, Becky, Kelly, and Ayinde are successfully gratified her esteem need.

\subsection{Self-Actualization}

A self-actualizatio is the highest level of needs and all of the characters in Little Earthquakes can fulfill their self- actualization. Kelly is full planning woman. She likes to organize all in her life to be something perfectionist. From this character she was choose work that have correlation with her characters. She was become event planner.

“Yoga Barbie's name turned out to be Kelly! An event planner! (LE, 2004: 13).

Similar with Kelly, Becky who's like eating and cooking improves her ability and becomes chef. She was struggling to develop her carrier until she become sexy chef and the owner of Mas restaurant

"Becky went from bussing to hostessing and waitressing. When she graduated, Darren the manager had hired her full-time". (LE, 2004: 68).

Self-actualization for Ayinde is to be house wife. She agrees with Baby Success by Priscilla Prewitt write that: 
"Before you had back to the salt mines, think carefully of the consequences of your choice. Babies are meant to love their mothers and to be cared for by their mother. Work if you must, but don't kid yourself. Remember that the woman you bring into your house to love your dumpling is going to get some of the hugs, some of the smiles, some of the sweet little giggles-in short, some of the love- that any baby would rather give to Mom." (LE, 2004: 136).

Another character is Lia, was get self-actualization being artist. When she was adult, she has dream to be artist in California.

"I'd chosen new name to go along with my slimmed-down body, the lips I plumped up, the nose I pared down, and the hair whose color I changed at least three times a year".(LE, 2004:62).

But, little earthquakes broke her carrier. But she has spirit to recovery her carrier. She was comeback to Philadelphia and being waitress in Mas restaurant.

"I started work next afternoon, standing in front of the sink in Mas's steamy kitchen, and peeling carrots until my fingers were numb. (LE, 2004: 221).

Based on the explanation above, all of the characters were able to achieve their selfactualization. It is work because they are work hard, struggle, and supporting each other.

\section{Conclusion}

Based on the findings above, there are four mothers struggling to fulfill their needs in life. Start from biological and psychological needs; Becky, Kelly and Ayinde are successfully completed this need, although Lia in the beginning of the story she was traumatic with little earthquakes that take her baby, and it was influence to her appetite. The second is safety needs. The only one who makes Lia feel safe when she get trauma from little earthquakes is her mother. Kelly is strong woman. She has brief characterization, which bring her in stability condition. Even Ayinde, as popular basketball's wife, sometimes she feels not safety when she in public.Third is a belongingness and love need. Based on this novel, the researcher surely agrees that this need can be fulfilled by all characters. Because the power of belongingness and love needs can they get from theirs. They have the power of friends or especially for them called motherhood. Next is esteem need. Although all of the character have problem to fulfill this needs, but finally Lia, Becky, Kelly, and Ayinde are successfully gratified her esteem need. The last is self-actualization. All of the characters were able to achieve selfactualization is not only by her struggle, but also supported by their good mental and moral and self-confidence.

\section{References}

Card, O. S. (1988). Characters and Viewpoint. Writer's Digest Books. F\&W Publications, Inc.

Maslow, A. (1970). Motivation and Personality. Second Edition. New York: Harper and Row. Inc.

Onah, F.O. (2015). Human Resource Management 4th Edition. Enugu: John Jacob's Classic Publishers Ltd.

Paris, B.J. Paris. (1996). Imagined Human Beings: A Psychological Approach to Character and Conflict in Literature. Detroit: Wayne State Univ. Press. 
Santrock,J.W. (2011). Educational Psychology Fifth Edition. New York: McGraw-Hill.

Todaro, M.P and Smith, S.C. (2009). Economic Development Tenth Edition. London: Addison - Wesley.

Weiner, J. (2011). Little Earthquakes. Jakarta: PT. Gramedia Pustaka Utama 